\title{
Application of ELISA for assessment of antiserum immunoreactivity in endocrine immunocytochemical studies
}

\author{
AC NIEUWENHUIJZEN KRUSEMAN \\ From the Departments of Endocrinology, St Bartholomew's Hospital, London EC1, and University Hospital, \\ Leiden, The Netherlands
}

SUMMARY An indirect method of an enzyme-linked immunosorbent assay (ELISA) is described to assess the reactivity of antisera used for the identification of peptide hormone producing cells by immunocytochemistry. Compared with radioimmunoassay and immunodiffusion, the ELISA 을 method has the advantages of simplicity and sensitivity and represents with the hormone $\vec{T}$ adsorbed to a matrix a situation more or less comparable to that in tissue sections. It is concluded that specificity testing of antisera applied in endocrine immunocytochemical studies can best be achieved by application of the ELISA method in combination with appropriate tissue controls.

The identification of peptide hormone secreting cells in tissue sections by immunocytochemistry is dependent on the specificity of the applied antibodies. This specificity is usually assessed by immunodiffusion or radioimmunoassay and confirmed by absorption of the antiserum with the target hormone antigen as a control in the immunostaining procedure. These procedures however are often insufficient to determine all wanted and unwanted immunoreactivities. Immunodiffusion techniques are insufficiently sensitive. The comparatively strong concentrations of antiserum required for immunocytochemistry may reveal cross-reactivities with related peptide hormones that are of little consequence in the dilutions applied for quantitative radioimmunoassay of plasma fluids or tissue extracts. Unless synthetic antigens are available for absorption of the antiserum, the specificity of this control procedure is illusory. For example, growth hormone antigen extracted from human post-mortem pituitaries used as an immunogen to raise growth hormone antibodies may be contaminated with a trace of prolactin. Absorption of the antiserum with this antigenic extract will fail to demonstrate the cross-reactivity to prolactin in immunostained sections.

Ideally, the cross-reactivities of peptide hormone antisera should be checked on serial concentrations of antigen in a solid phase mimicking the situation in tissue sections. ${ }^{1}$ For this reason I have applied an

Accepted for publication 8 November 1982 indirect method using an enzyme-linked immunosorbent assay (ELISA) in which the hormone antigens are adsorbed on to the walls of the cups of polystyrene microtitre plates. ${ }^{23}$ Serial dilutions of the antisera are added to the cups and after incubation positive reactivities are demonstrated by the addition of a peroxidase-labelled anti-IgG and the development of a peroxidase-dependent chromogenic reaction. The method proved to be $\overline{8}$ sensitive and adequate and revealed unexpected : cross-reactivities. The quantitative aspects indicated 3 the degree of dilution of antiserum required to annul $\delta$ trace cross-reactivities and the necessity to discard or further refine antisera in which cross-reactivities 을 were marked. In this paper the method is illustrated by the investigation of the immunoreactivities of antisera against the pituitary hormones prolactin and growth hormone and between portions of the $\sigma$ pro-opiocortin molecule-namely, $\gamma_{3}-\mathrm{MSH}, \mathrm{ACTH}$ O and $\beta$-LPH (Fig. 1). The results are compared with $\underset{\omega}{N}$ results of immunohistochemical staining.

\section{Material and methods}

MATERIAL

\section{Hormones}

Preparations of human prolactin, growth hormone $\frac{\sim}{\mathbb{D}}$ and $\beta$-LPH were donated by Dr PJ Lowry. These $\frac{\varrho}{\sigma}$ hormones were obtained by extraction and purification of post-mortem pituitaries. ${ }^{4-6}$ Synthetic 


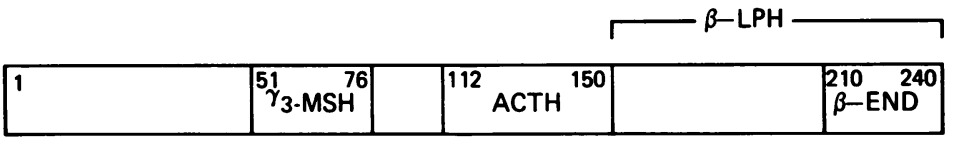

Fig. 1 Diagram of pro-opiocortin

$\gamma_{3}-\mathrm{MSH}$ was donated by Dr $\mathrm{N}$ Ling. Porcine 1-39 ACTH was purchased from Armour (Acthar) and synthetic 1-24 ACTH (Synacthen) was purchased from Ciba.

\section{Antisera}

These were all raised in rabbits. The antisera against human prolactin, growth hormone, synthetic $\beta$-endorphin and porcine ACTH were donated by Dr PJ Lowry. The $\gamma_{3}-\mathrm{MSH}$ antiserum was donated by Prof LH Rees. These antibodies do not show non-specific immunoreactivities in radioimmunoassay. Since the complete amino acid sequence of $\beta$-endorphin is present in $\beta$-LPH (Fig. 1 ), the $\beta$-endorphin antiserum is reactive with $\beta-\mathrm{LPH}$ as well. Peroxidase-labelled porcine antirabbit IgG was purchased from Dako.

\section{METHODS}

\section{Enzyme-linked immunosorbent assay (ELISA)}

An indirect method was used ${ }^{23}$ as follows:

(i) Disposable polystyrene microtitre plates (Dynatech) were washed in $0.1 \mathrm{~mol} / \mathrm{H} \mathrm{HCl}$ and distilled water and coated with the hormones mentioned above by adding to each cup $50 \mu$ l of the hormone solution $(1 \mu \mathrm{g} / \mathrm{ml})$ in $0.1 \mathrm{~mol} / \mathrm{l}$ sodium carbonate buffer (pH 9.6) with $0.02 \%$ sodium azide, and incubating the plates at $37^{\circ} \mathrm{C}$ in a moist atmosphere for $3 \mathrm{~h}$. Plates containing the hormone solution were stored at $4^{\circ} \mathrm{C}$ until use.

(ii) Before assay the plates were washed three times for $5 \mathrm{~min}$ each with PBSA, composed of $0.01 \mathrm{~mol} / \mathrm{l}$ phosphate buffer ( $\mathrm{pH} 7 \cdot 4), 0 \cdot 15 \mathrm{~mol} / \mathrm{l} \mathrm{NaCl}$ and $1 \%$ bovine serum albumin (type V, Sigma).

(iii) The plates were then incubated at $37^{\circ} \mathrm{C}$ for 30 min with $50 \mu \mathrm{l}$ per cup of serial dilutions of the antisera in PBSA.

(iv) Washed three times for 5 min each with PBSA.

(v) Incubated at $37^{\circ} \mathrm{C}$ for $30 \mathrm{~min}$ with $50 \mu \mathrm{l}$ per cup of porcine antirabbit IgG conjugated with peroxidase diluted to $1 / 200$ in PBSA.

(vi) Washed again three times for 5 min each with PBSA.

(vii) Finally incubated with $100 \mu$ l per cup of the enzyme substrate solution at room temperature. The reaction was stopped after about one hour by addition of $25 \mu l 1 \mathrm{~N} \mathrm{NaOH}$ to each cup.

The substrate used was a mixture of 5-aminosalicylic acid (5-AS, Merck) and $\mathrm{H}_{2} \mathrm{O}_{2}$ prepared according to Ruitenberg et $\mathrm{al}^{7}$ as follows: $80 \mathrm{mg}$ of 5-AS were dissolved in $100 \mathrm{ml}$ hot distilled water and filtered. Immediately before use the $\mathrm{pH}$ of this stock solution was brought to 6.0 with 1 $\mathrm{N} \mathrm{NaOH}$, and $25 \mu \mathrm{l}$ of $30 \% \mathrm{H}_{2} \mathrm{O}_{2}$ was added. The amount of brown reaction product was evaluated visually. The optimal quantity of hormone to be coupled to the plates and the dilution of peroxidase-labelled IgG were determined by chess-board titration. Following this procedure optimal sensitivity was achieved when 10 to $100 \mathrm{ng}$ of the hormones were coated per cup (Fig. 2).

\section{Immunocytochemistry}

Four $\mu \mathrm{m}$ sections of formalin-fixed paraffin-wax embedded tissues of normal human pituitaries and pituitary adenomas from patients with either Cushing's disease, acromegaly or a prolactinoma were subjected to an indirect immunocytochemical method with peroxidase-labelled antibodies. ${ }^{38}$ After exposure to the antibodies the peroxidase-labelled hormone-antibody complexes were visualised with an enzyme substrate medium 3.3'-diaminobenzidine (Sigma) and $\mathrm{H}_{2} \mathrm{O}_{2}$ in Tris buffer.

\section{Controls}

These included direct addition of the peptide hormone antigens to the antisera and incubation overnight at $4^{\circ} \mathrm{C}$.

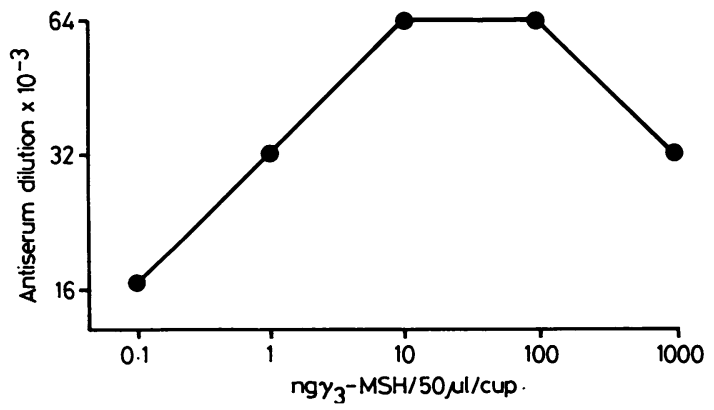

Fig. 2 Effect of the quantity of $\gamma_{3}-M S H$ coated to the microtitre plate on the sensitivity of the ELISA method. Optimal sensitivity is achieved when 10 to $100 \mathrm{ng}$ of this peptide are coated per cup. 


\begin{tabular}{|c|c|c|c|c|c|c|}
\hline & \multicolumn{5}{|c|}{ Immunoreactivity determined with the ELISA technique } & \multirow{2}{*}{$\begin{array}{l}\text { Cell type stained with } \\
\text { immunocytochemistry }\end{array}$} \\
\hline & $G H$ & $P R L$ & $\gamma_{3}-M S H$ & $A C T H$ & $\beta-L P H$ & \\
\hline $\begin{array}{l}\text { anti-GH } \\
\text { anti-PRL } \\
\text { anti-GH pretreated with GH } \\
\text { anti- } \gamma_{3}-\text { MSH } \\
\text { anti-ACTH } \\
\text { anti- } \beta \text {-endorphin } \\
\text { anti- } \gamma_{3}-\text { MSH pretreated } \\
\quad \text { with } 1-24 \text { ACTH }\end{array}$ & $\begin{array}{l}32000^{*} \\
\text { nil } \\
\text { nil } \\
\text { nil } \\
\text { nil } \\
\text { nil } \\
\text { nil }\end{array}$ & $\begin{array}{l}4000 \\
16000 \\
\text { nil } \\
\text { nil } \\
\text { nil } \\
\text { nil }\end{array}$ & $\begin{array}{l}\text { nil } \\
\text { nil } \\
\text { nt } \\
64000 \\
\text { nil } \\
\text { nil }\end{array}$ & $\begin{array}{l}200 \\
\text { nil } \\
\text { nt } \\
2000 \\
3200 \\
\text { nil }\end{array}$ & $\begin{array}{l}\text { nil } \\
200 \\
\text { nt } \\
8000 \\
<200 \\
8000\end{array}$ & $\begin{array}{l}\text { Somatotroph } \\
\text { Lactotroph } \\
\text { Corticotroph } \\
\text { Corticotroph } \\
\text { Corticotroph }\end{array}$ \\
\hline
\end{tabular}

${ }^{*}$ Reciprocal of antiserum dilution at which immunoreactivity is still present.

\section{Results}

The results of the investigations are summarised in the Table. With the ELISA technique all the antisera showed distinct immunoreactivities with the hormones against which they were raised. The growth hormone antiserum showed additional cross-reactivity with prolactin and to a moderate degree with ACTH. The cross-reactivity of this antiserum with prolactin was quenched by pretreatment of the antiserum with excess growth hormone (10 $\mu \mathrm{g} / \mathrm{ml}$ antiserum diluted to $1 / 1000$ in PBSA). The prolactin antiserum showed some cross-reactivity with $\beta$-LPH. The $\gamma_{3}-\mathrm{MSH}$ antiserum showed crossreactivity with both ACTH and $\beta$-LPH. This crossreactivity was quenched after pretreatment with synthetic 1-24 ACTH $(10 \mu \mathrm{g} / \mathrm{ml}$ antiserum diluted to $1 / 1000$ in PBSA). The ACTH antiserum showed scanty cross-reactivity with $\beta$-LPH. The $\beta$-endorphin antiserum was reactive with $\beta$-LPH only.

With immunocytochemistry, all the antisera were reactive with only those cells in normal and adenomatous pituitary tissues of which it could be assumed by comparison with adjacent sections and on clinical data, that they contained the hormone against which the antiserum was raised (Table; Figs. 3 and 4). The final antiserum dilution appropriate for immunocytochemistry was in all instances about five times lower than the highest dilution at which immunoreactivity was still present with the ELISA method.

\section{Discussion}

The use of immunocytochemistry in endocrine investigations requires a twofold specificity of the relevant antiserum: the antiserum should only react with the hormone against which the antiserum is raised, and the binding should be restricted to unique antigenic determinants that are not present on other portions of the prohormone from which the

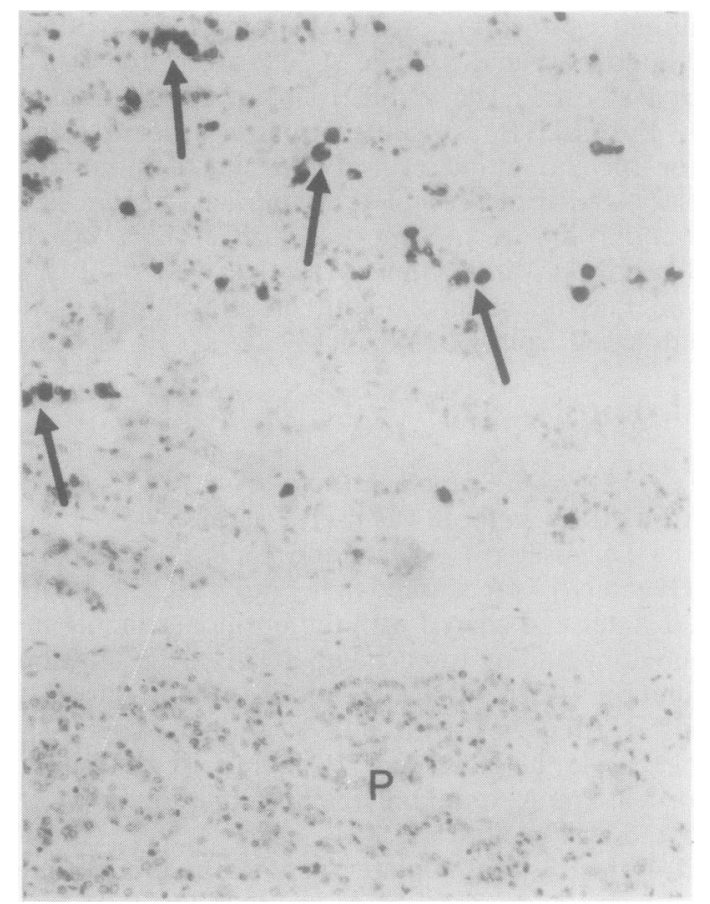

Fig. 3 Human pituitary containing a prolactinoma, immunostained with the growth hormone antiserum. Distinct growth hormone immunoreactivity is present in pre-existent pituitary cells, but not in adenoma cells. Diaminobenzidine $\times \mathbf{4 0 0}$

relevant hormone is derived. In our experience the indirect method of the enzyme-linked immunosorbent assay (ELISA) is more suitable than immunodiffusion, radioimmunoassay or incubation of tissue sections with absorbed antisera to assess these specificities. The method is cheap, simple and rapid to perform. It does not use radionuclides. It does not require large quantities of usually expensive hormones. It is also sensitive to antibodies of low titre and avidity. It is quantitative for the anti- 


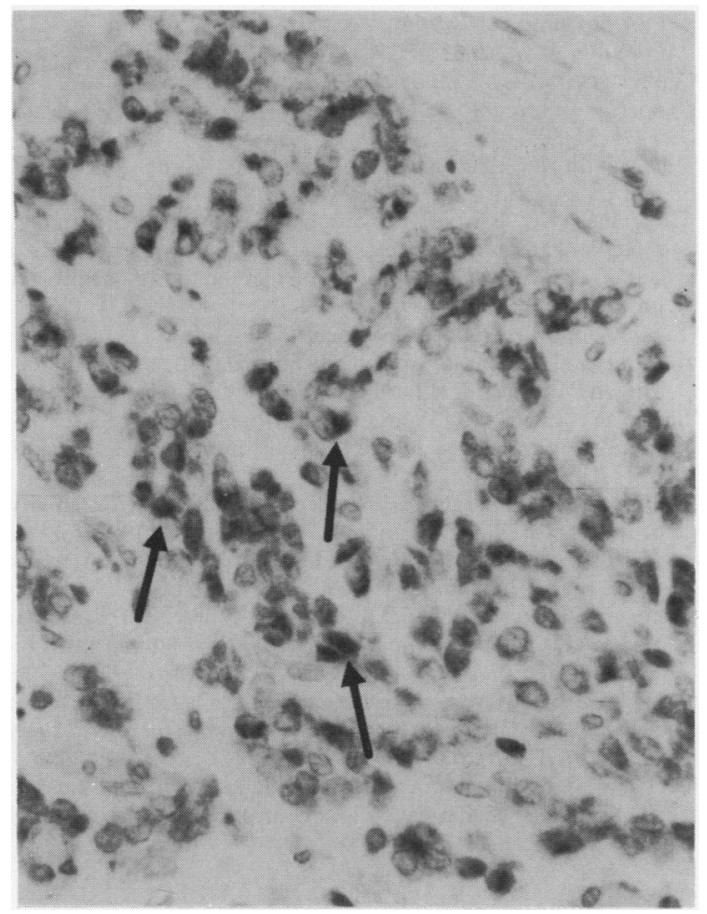

Fig. 4 Higher magnification of the prolactinoma shown in Fig. 3, immunostained with the prolactin antiserum. Distinct prolactin immunoreactivity is present in adenoma cells. Diaminobenzidine $\times 1000$

body. Finally, it represents, with the hormone attached to a matrix, a situation more or less comparable to that of the hormone fixed in a tissue section.

For visual reading of ELISA results we prefer 5-aminosalicylic acid as chromogenic substrate in the enzyme reaction. This compound is partially insoluble and therefore not very suitable for photometric reading. Since another peroxidase substrate, $o$-phenylene diamine, is completely soluble and renders a high extinction coefficient, this compound is recommended as the preferable substrate for photometric reading. ${ }^{2}$ However, the dark-brown reaction product obtained after 5-aminosalicylic acid enables easier differentiation by eye between specific and background coloration than the orange reaction product obtained after $o$-phenylene diamine.

In our hands, the optimal amount of hormone to be coated to the microtitre plates usually varies between 10 to $100 \mathrm{ng} / \mathrm{cup}$. As illustrated in Fig. 2, coating of more than the optimal quantity results in a decrease of sensitivity, which is possibly due to occurrence of physical hindrance to the entry of the antibodies.
Because of its high sensitivity, the ELISA method may reveal scanty cross-reactivities that are not relevant for immunocytochemical staining. For instance, the growth hormone and prolactin antisera showed some cross-reactivity with respectively ACTH and $\beta$-LPH, but were not reactive with corticotropic cells in tissue sections. On the other hand, cross-reactivities demonstrated with the ELISA method may not be due to the presence of nonspecific antibodies in the antiserum, but instead be caused by contamination of the hormone preparation used for the coating and testing with the hormone with which the antiserum is cross-reactive. This is most likely the explanation for the finding that with the ELISA method the growth hormone antiserum showed distinct cross-reactivity with prolactin, whereas no reaction of this antiserum with prolactin cells in tissue sections was observed (Figs. 3 and 4).

Pretreatment of the growth hormone antiserum with excess growth hormone quenched the crossreactivity with prolactin in the ELISA method, indicating that the cross-reaction of this antiserum with the prolactin antigen was not due to the presence of prolactin antibodies in the growth hormone antiserum, but caused by contamination of the prolactin antigen used for the coating and testing in the ELISA method with growth hormone. This confirms that antigens obtained by extraction are often contaminated and therefore not very useful for absorption controls on tissue sections.

Discrepancies between results obtained with ELISA and immunocytochemistry as is demonstrated for growth hormone and prolactin, are less clear when the peptides with which the antiserum is cross-reactive are localised in the same cell as the specific peptide. For instance, staining of corticotropic cells with antisera against portions of the pro-opiocortin molecule (Fig. 1) may be due either to presence of the relevant portion of pro-opiocortin or to cross-reaction with other portions which share antigenic determinants. This is obviously the case with the $\gamma_{3}-\mathrm{MSH}$ antiserum, which was reactive with ACTH and $\beta$-LPH as well with ELISA. $\gamma_{3}-\mathrm{MSH}$, ACTH and $\beta$-LPH have a four amino acid sequence in common, which in ACTH is present at the 6-9 position. Pretreatment of the $\gamma_{3}-\mathrm{MSH}$ antiserum with synthetic 1-24 ACTH quenched the crossreactivity with ACTH and $\beta$-LPH, but did not affect the reaction of the antiserum with corticotropic cells in tissue sections. This illustrates the suitability of the ELISA technique to demonstrate that the pretreatment with 1-24 ACTH was sufficient to neutralise the cross-reactivity with ACTH and $\beta$-LPH and that the final immunoreaction of the $\gamma_{3}-\mathrm{MSH}$ antiserum with corticotropic cells is due to the presence 
of $\gamma_{3}$-MSH immunoreactivity in these cells.

As is the case for all methods applied in specificity testing of antibodies, a limitation of the ELISA method is that only immunoreactivities with peptides that are known and available for testing can be studied. Even when monoclonal antibodies are used, reactivities with unknown peptides usually remain hidden, unless the results of the ELISA and immunocytochemical staining are correlated with clinical data and biological and chromatographic analysis of tissue extracts with which the antibodies are reactive. As even this approach may be insufficient to demonstrate non-specificities, it is highly questionable whether specificity can be proven in immunocytochemistry. ${ }^{9}$ I feel however that within the limits of imperfection, assessment of reactivities of antisera to be used in endocrine immunocytochemistry can ultimately best be achieved when the ELISA method is used in combination with appropriate tissue controls. ${ }^{10}$

I am grateful to Dr PJ Lowry and Prof I Doniach for interest and advice during the investigations and preparation of the manuscript, and to Dr Barbara Smith for laboratory facilities. This work was supported by a Royal Society Travel Grant.

\section{References}

' van Raamsdonk W, Pool CW, Heyting C. Detection of antigens and antibodies by an immuno-peroxidase method applied on thin longitudinal sections of SDS-polyacrylamide gels. $J$ Immunol Methods 1977;17:337-48.

${ }^{2}$ Voller A, Bartlett A, Bidwell DE. Enzyme immunoassays with special reference to ELISA techniques. J Clin Pathol 1978;31:507-20.

${ }^{3}$ Nieuwenhuijzen Kruseman AC. Immunolocalization of pituitary hormones. Leiden: MD Thesis, 1976.

${ }^{4}$ Hodgkinson SC, Lowry PJ. Hydrophobic-interaction chromatography and anion-exchange chromatography in the presence of acetonitrile. A two-step purification method for human prolactin. Biochem J 1981;199:619-27.

${ }^{5}$ Lumley-Jones R, Benker G, Salacinski PR, Lloyd TJ, Lowry PJ. Large-scale preparation of highly purified pyrogen-free human growth hormone for clinical use. J Endocrinol 1979;82:77-86.

- Scott AP, Lowry PJ. Adrenocorticotrophic and melanocytestimulating peptides in the human pituitary. Biochem $J$ 1974;139:593-602.

${ }^{7}$ Ruitenberg EJ, Steerenberg PA, Brosi BJM, Buys J. Reliability of the enzyme-linked immunosorbent assay (ELISA) for the serodiagnosis of trichinella spiralis infection in conventionally raised pigs. J Immunol Methods 1976;10:67-83.

${ }^{8}$ Nieuwenhuijzen Kruseman AC, Linton EA, Lowry PJ, Rees LH, Besser GM. CRF-41 immunoreactivity in the human gastrointestinal tract. Lancet 1982;ii:1245-6.

- Swaab DF, Pool CW, van Leeuwen FW. Can specificity ever be proved in immunocytochemical staining? J Histochem Cytochem 1977;25:388-91.

${ }^{10}$ Heyderman E. Immunoperoxidase technique in histopathology: applications, methods and controls. J Clin Pathol 1979;32:971-8.

Requests for reprints to: Dr AC Nieuwenhuijzen Kruseman, Department of Endocrinology, University Hospital, Rijnsburgerweg 10, 2333 AA Leiden, The Netherlands. 